\title{
Energy balance in the watershed of Ipê, Northwestern São Paulo State, Brazil
}

Diego G. Feitosa, Fernando B. T. Hernandez, Renato A. M. Franco, Antonio H. C. Teixeira, Christopher M. Neale

Diego G. Feitosa, Fernando B. T. Hernandez, Renato A. M. Franco, Antonio H. C. Teixeira, Christopher M. Neale, "Energy balance in the watershed of Ipê, Northwestern São Paulo State, Brazil ," Proc. SPIE 9998, Remote Sensing for Agriculture, Ecosystems, and Hydrology XVIII, 999800 (25 October 2016); doi: $10.1117 / 12.2242137$

SPIE. Event: SPIE Remote Sensing, 2016, Edinburgh, United Kingdom 


\title{
Energy balance in the watershed of Ipê, Northwestern São Paulo State, Brazil
}

\author{
Diego G. Feitosa ${ }^{a}$, Fernando B. T. Hernandez ${ }^{* a}$, Renato A. M. Franco ${ }^{a}$, Antonio H. C. \\ Teixeira $^{\mathrm{b}}$, Christopher M. Neale \\ ${ }^{a, b}$ UNESP - - São Paulo State University, P.O. Box 34, Ilha Solteira, SP, Brazil; ${ }^{b}$ Embrapa \\ Satellite Monitoring, Campinas, São Paulo, Brazil, ${ }^{\mathrm{C}}$ Water for Food Global Institute at the University \\ of Nebraska, Lincoln, USA
}

\begin{abstract}
The region of Ilha Solteira, in the Northwestern of São Paulo State, has been undergoing significant changes in agricultural land use and cover since 2006, as pasture fields have been replaced by sugarcane crop. This drastic change can lead to a disturbance in the energy balance, affecting the local climate. The aim of this paper was to assess some parameters related to the energy balance of Ipê's watershed, that changed since no sugarcane cultivation in 2006 to 2,164 hectares in 2011, occupying $31 \%$ of the catchment area with this important energy crop for the economy and the environment of Brazil. This study was carried out using remote sensing combined with weather data and using the SAFER (Simple Algorithm for Retrieving Evapotranspiration) model applied in 9 Landsat images collected between 2003 and 2011. The results showed a wide variation between the components of energy balance and when considering only the sugarcane crop were verified the increase values of ETa (Actual Evapotranspiration), H/Rn (Sensible Heat Flux/Net Radiation), TS (Surface Temperature), Rl $\uparrow$ (Emitted longwave), R1 $\downarrow$ (Incidente longwave) and surface albedo after the sugarcane production over these years. On the other hand, the NDVI, $\lambda E / R n$ (Latent Heat Flux/Net Radiation) and Rn values (data) decreased in the same period. Also there was satisfactory correlation between NDVI and ETa. The SAFER model showed satisfactory results for studies of energy balance applied in the Northwestern of São Paulo State.
\end{abstract}

Keywords: Sugar cane. Net radiation. Latent heat flux. Sensible heat flux.

\section{INTRODUCTION}

Little is being studied about climate changes that may happen in a region, with the entry of a determined culture in long continuous areas. This change of usage and occupation of soil is found in almost all São Paulo state, where as between the years of 2001 and 2006, 1.45 million hectares have had their occupation replaced by new cultures; of this total, $69.79 \%$ were previously occupied by pasture, being that the culture that most occupied these new areas was sugar cane, with $67.33 \%$ of the total area ${ }^{1}$. Being that in the region of Andradina, which incorporates the studied area, the absorbed percentage by sugar cane came up to $75.37 \%$.

This change of earth usage behavior was also observed in all the area of the Ipé's watershed, with sugar cane's crop cultivation which represented $48.1 \%$ of all the watershed $\operatorname{area}^{2}$. The cultivation indicated that in the region of Ilha Solteira until 2006, in areas previously dominated by pastures, that in the year of 2003, occupied a territory extension of $432.28 \mathrm{Km}^{2}$, representing $66.79 \%$ of the municipal area ${ }^{3}$. In 2009, of only 68 hectares in the 2004/2005 harvest, sugar cane passed 14,714 hectares, being cultivated in areas where pasture was before ${ }^{4}$.

The use of remote sensing by satellite images has been proving a very interesting tool for energy balance quantification. This tool presents the advantage of the possibility of being used not only in a spatial scale, but also in a timescale, allowing studies to be conducted throughout years at a time. This way satellite images of different resolutions have been used for obtaining information on extensive areas ${ }^{5}$.

*fbthtang@agr.feis.unesp.br; phone +55 18 3743-1939 - http://www.agr.feis.unesp.br/irrigacao.php

Remote Sensing for Agriculture, Ecosystems, and Hydrology XVIII, edited by

Christopher M. U. Neale, Antonino Maltese, Proc. of SPIE Vol. 9998, 999800

(C) 2016 SPIE · CCC code: $0277-786 X / 16 / \$ 18 \cdot$ doi: $10.1117 / 12.2242137$

Proc. of SPIE Vol. 9998 999800-1 
The use of remote sensing via satellite images has been proving a very interesting tool for energy balance quantification. This tool presents the advantage of the possibility of being used not only in a spatial scale, but also in a timescale, allowing studies to be conducted throughout years at a time. This way satellite images of different resolutions have been used for obtaining information on extensive areas ${ }^{5}$.

In this context many studies were developed in these last years, including the region studied itself, using the Surface Energy Balance Algorithm for Land algorithm - SEBAL ${ }^{6,7,8}$, however, this algorithm demands the presence of extreme hydrological conditions in the scene, leading to smaller data precision, if the operator doesn't have the necessary practice while choosing hot and cold pixels, specially in a rainy period, when latent heat flow values occur in the image.

With this, the use of the Simple Algorithm For Evapotranspiration Retrieving - SAFER ${ }^{9}$ was chosen for the execution of this study, it possesses a simpler application, needing only evapotranspiration data as reference $\left(\mathrm{ET}_{0}\right)$, global radiation $(\mathrm{Rg})$ and average temperature (Ta) obtained by the agrometeorological stations so that, along with the parameters obtained by remote sensing, get to the energy balance including the current - actual - evapotranspiration (ETa).

The objective of this study was to analyze spatial and temporal variation of energy balance in the Ipé's watershed all through the period of 2003 to 2011 for the dry period, aiming to identify if there was an interference with the change in earth usage that occurred in this region with the entrance of sugar cane culture.

\section{MATERIAL AND METHODS}

Radiation and energy balance was done for the Ipê's watershed (Figure 1), located in the city of Ilha Solteira, in the northwest region of the State of São Paulo, making an area of 5,044 hectares, corresponding to 7.68\% of the city's territorial extension ${ }^{2}$.

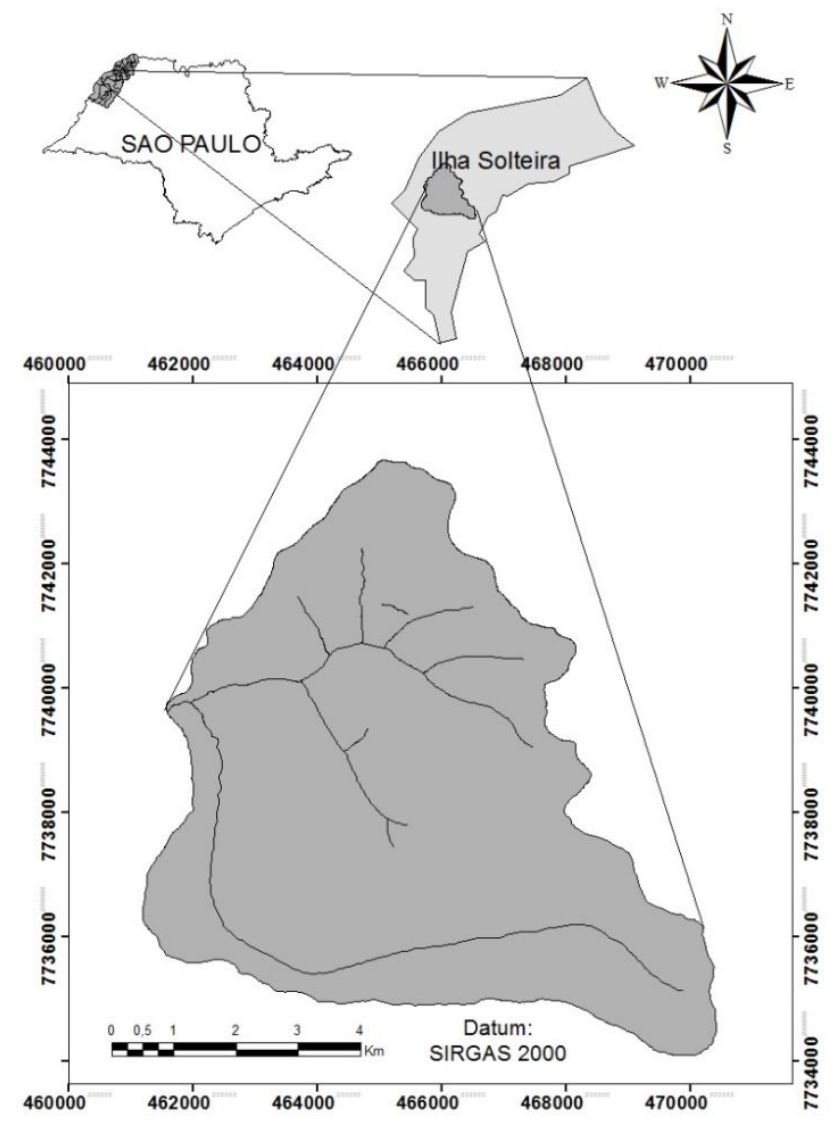

Figure 1. Localization of the Ipê's watershed. 
The studied region shows extended water deficits during eight months a year and the biggest rate of reference evapotranspiration $\left(\mathrm{ET}_{\mathrm{o}}\right.$ ) of the State of São Paulo, with susceptibility to dry spells ${ }^{10 ; 11 ; 12 ; 13}$, even though with a historic average annual rainfall (1967-1994) of $1,232 \mathrm{~mm}^{12}$ or of $1,354 \mathrm{~mm}^{10}$ in the period of 2000 to 2010.

Furthermore, the watershed presents an urban area close to the countryside, raising the importance of monitoring temporal evolution and the aggravation of effects of the urban heat island. Being that the watershed receives direct influence from the urban area with an expansion expectation and thus, considering the strategic importance by the municipal Director Plan approved in $2008^{14}$.

For the execution of the radiation and energy balance, nine Landsat Thematic Mapper TM-5 images were used, with Orbit 222 and Point 74, acquired in clear sky conditions for the period of 2003 to 2011. Choosing images based on the hydrological period, with images obtained between the months of June and August, for being in the dry period ${ }^{10,13}$. In a way, other than representing itself critical, due to the lack of rain, it favors radiation and energy balance studies by the use of satellite images, because of the lack of clouds.

Reference evapotranspiration (ET $\left.{ }_{0}\right)$ was calculated by using the Penman-Monteith ${ }^{15}$ method, global radiation $(\mathrm{Rg})$ and average air temperature $\left(\mathrm{T}_{\mathrm{a}}\right)$ were obtained by using automatic agrometeorological stations located in the northwest of São Paulo State, in the cities of Ilha Solteira and Marinópolis ${ }^{16}$. Next, the data was interpolated by the Moving Average method and posteriorly inserted in the algorithm used to obtaining present evapotranspiration (ETa) and in radiation and energy balance.

The SAFER was applied with ILWIS (Integrated Land Water Information System) software in the script function ${ }^{7,}$. Initially, atmospheric corrections were made with later conversion of spectral radiation ${ }^{17,18}$. The albedo surface $\left(\alpha_{0}\right)$ data, surface temperature $\left(\mathrm{T}_{0}\right)$ and NDVI (Normalized Difference Vegetation Index), are used to calculate the instantaneous values of $\mathrm{ET}_{\mathrm{a}} / \mathrm{ET}_{0}$ values (Equation 1), where the value of 1.0 was for the coefficient "a"19 and the value of -0.008 corresponded to the coefficient " $\mathrm{b}^{\text {"7 }}$. Next, the instantaneous values of this relation are multiplied by the daily values of $\mathrm{ET}_{0}$, thus getting to $\mathrm{ET}_{\mathrm{a}}$.

$$
\frac{\mathrm{ETa}}{\mathrm{ET}_{0}}=\exp \left[\mathrm{a}+\mathrm{b}\left(\frac{\mathrm{TS}}{\propto_{0} \mathrm{NDVI}}\right)\right]
$$

Within the calculation of energy and radiation balance, the $\mathrm{R}_{\mathrm{g}}$ was obtained in the pyranometers of the agrometeorological stations. The long incident wave ( $R L \downarrow$ ) was calculated by the Stefan-Boltsman equation, using the values of $T_{a}$. The values of $R_{n}$ were obtained by equation 2

$$
R n=\left(1-\propto_{0}\right) \operatorname{Rg} \downarrow-a \tau_{s w}
$$

Where $\mathrm{Rg} \downarrow$ in $\mathrm{W} / \mathrm{m}^{2}, a$ is a regression coefficient between the radiation balance of long waves and atmospheric transmissivity of short waves $\left(\tau_{\mathrm{sw}}\right)$ being obtained by the following equation:

$$
\mathrm{a}=\mathrm{bT}_{\mathrm{a}}-\mathrm{c}
$$

Being so that " $\mathrm{b}$ " and "c" are regression coefficients obtained for the semiarid Brazilian conditions ${ }^{20}$, respectively 6.99 and 39.93. The values of Ta correspond to the interpolation of data the average air temperature data.

Latent heat flux $(\lambda \mathrm{E})$ were obtained through $\mathrm{ET}_{\mathrm{a}}$ conversion in energy units, later the values of $\mathrm{H}$ (sensitive heat flux) were determined as a energy balance residue, assuming that for this the heat flux values in the soil (G) correspond to 0 for the period of 24 hours:

$$
\mathrm{H}=\mathrm{R}_{\mathrm{n}}-\lambda \mathrm{E}
$$

After obtaining the images, these images were imported in the ArcGis ${ }^{\circledR} 10$ software, where average values of the biophysical parameters were obtained, which make up the energy balance for Ipê's watershed's total area. The average values of $\mathrm{ET}_{\mathrm{a}}, \lambda \mathrm{E} / \mathrm{R}_{\mathrm{n}}, \mathrm{H} / \mathrm{R}_{\mathrm{n}}$ and surface temperature were also separately obtained for four classes of soil usage, being these the urban area, pasture, green cane and harvested cane, where urban area zones and pastures were identified by a natural Red, Green and Blue (RGB) composition, correspondingly to the bands 3, 2, and 1, the sugarcane areas were identified and quantified by using Canasat ${ }^{21,22}$ data thus reaching the area of interest inside the watershed. The sugarcane areas were divided in green cane, which correspond to the areas in adult stage and harvested cane, planted recently and/or are in preparation phase. 


\section{RESULTS AND DISCUSSION}

In Table 1, dates of images are found, the evolution of total cultivated area with sugarcane, the sugarcane area in an adult phase (featured by soil coverage) and the ratio between this area of not yet picked cane by the total area, verifying that this started being cultivated in the Ipê's watershed since 2007, with a total area of 326.78 hectares, being that $90 \%$ was occupied with an already adult phase culture. Next year, the cane suffered an increase of over $500 \%$, increasing to 1,823.98 hectares, in 2009 the expansion was of only 347.21 hectares, increasing to a total of 2,171.19 hectares, this area remaining stable in the next two years.

The images used in the identification of sugarcane areas coincide with the harvesting period, thus providing a variation in the area occupied by culture, where the presence of areas with cane occur in an adult phase (EA) and of waste areas (post harvest) or in sprout phase.

In the image of 2008 , less than $30 \%$ of cane area, was in an adult phenological phase (AS), which compromises the diagnosis of real cane culture influence in the energy and radiation balance components of the watershed. In the State of São Paulo, the months of September and November are the most indicated for identifying the spectral characteristic answer of sugarcane culture, for a bigger homogeneity of $\operatorname{areas}^{23}$. However, this fact can be relativized, since each power plant has a its own harvest strategy which prioritizes determined areas, by distance, by maturation stage, thus, studying the influence of sugarcane culture on energy balance conditions, it is important to pay attention to the differences between harvested area and the fully fledge or maturation area, shown in Table 1.

Table 1. Julian Day (J.D.) and Year of the Image, Total Area-TA (ha), Adult Stage-AS (ha) and EA/AT for the sugarcane culture in the Ipê's watershed in the city of Ilha Solteira-SP.

\begin{tabular}{cccc}
\hline J.D. and Year of the Image & Total Area - TA (ha) & Adult Phase - AS (ha) & AS/TA \\
\hline $174 / 2003$ & 0.00 & 0.00 & 0.00 \\
$209 / 2004$ & 0.00 & 0.00 & 0.00 \\
$195 / 2005$ & 0.00 & 0.00 & 0.00 \\
$198 / 2006$ & 0.00 & 0.00 & 0.00 \\
$185 / 2007$ & 326.78 & 295.39 & 0.90 \\
$204 / 2008$ & $1,823.98$ & 497.00 & 0.27 \\
$238 / 2009$ & $2,171.19$ & $1,348.22$ & 0.62 \\
$241 / 2010$ & $2,166.34$ & $1,273.79$ & 0.59 \\
$196 / 2011$ & $2,164.08$ & 669.01 & 0.31 \\
\hline
\end{tabular}

Observing the behavior of $R_{g} \downarrow$ and $R_{g} \uparrow$ throughout the years (Table 2) it isn't possible to find any significant differences, being that the short wave incident radiation $\left(\mathrm{R}_{\mathrm{g}} \uparrow\right)$ which is independent of culture, but it is important to show atmospheric demand, it oscillates throughout the years presenting an average of $17.72 \mathrm{MJ} \mathrm{m}^{-2}$ day ${ }^{-1}$, varying between a maximum of $22.34 \mathrm{MJ} \mathrm{m}^{-2}$ day $^{-1}$ in 2009 and a minimum of $12.77 \mathrm{MJ} \mathrm{m}^{-2}$ day $^{-1}$ in $2003^{16}$.

By relating the Julian Day from the data from the image (Figure 2) it is observed that the high quadratic correlation for $R_{g} \downarrow$ and $R_{g} \uparrow$, being, respectively, that the values of $R^{2}$ of 0.77 and 0.90 . This behavior shows that the values of $R_{g} \downarrow$ and $\mathrm{R}_{\mathrm{g}} \uparrow$, were influenced by the time of the year and not by the occupation of the use of the soil which happened throughout the years.

Different behavior was found for the data of $\mathrm{ET}_{\mathrm{a}}$ and NDVI which present a decrease of values throughout the years, with the exception of the years of 2003 and 2005, and for NDVI in 2003, which are found above average (Figure 2). The high values found for $\mathrm{ET}_{\mathrm{a}}$ and NDVI these years are justified by the high results of $\mathrm{ET}_{\mathrm{a}} / \mathrm{ET}_{0}$ relation which can also be called a crop coefficient $\left(\mathrm{K}_{\mathrm{c}}\right)$, but always referred as obtained when with great conditions, without water restriction ${ }^{15}$. In the conditions of work, the $\mathrm{ET}_{\mathrm{a}} / \mathrm{ET}_{0}$ ratio can be called the current or actual crop coefficient and indicate the amount of 
water lost to the atmosphere by evapotranspiration process relative to $\mathrm{ET}_{0}$ and can change of the soil water storage function or the crop phenological stage at the time of passage of the satellite and range roughly of 0.55 and 0.35 for 2003 and 2005, respectively, meanwhile the average for the whole period was 0.21 (Table 2). In turn the high value of $\mathrm{ET}_{\mathrm{a}} / \mathrm{ET}_{0}$ these years are due to the probable presence of humidity in the soil, proven by the ratio between latent heat flux and net radiation of 0.54 in 2003 and 0.52 in 2005, showing that the larger part of the radiation balance was used in the process of evapotranspiration.

Table 2. Julian Day (J.D.) and Year of Image, NDVI, relation $\mathrm{ET}_{\mathrm{a}} / \mathrm{ET}_{0}$, current evapotranspiration $\left(\mathrm{ET}_{\mathrm{a}}\right.$ ), incident short waves $\left(R_{g} \downarrow\right)$, radiation of short waves issued by the surface $\left(R_{g} \uparrow\right)$, incident long waves radiation (R1 $\left.\downarrow\right)$ and long wave radiation issued by the surface $(\mathrm{R} 1 \uparrow)$.

\begin{tabular}{|c|c|c|c|c|c|c|c|}
\hline \multirow{2}{*}{$\begin{array}{l}\text { J.D. and Year } \\
\text { of Image }\end{array}$} & \multirow{2}{*}{ NDVI } & \multirow{2}{*}{$\left(\mathrm{ET}_{\mathbf{a}} / \mathbf{E T}_{\mathbf{0}}\right)$} & \multirow{2}{*}{$\begin{array}{l}\mathrm{ET}_{\mathrm{a}} \\
\left(\mathrm{mm} \text { day }^{-1}\right)\end{array}$} & $\mathbf{R}_{\mathrm{g}} \downarrow$ & $\mathbf{R}_{\mathrm{g}} \uparrow$ & $\mathbf{R I} \downarrow$ & $\mathbf{R I} \uparrow$ \\
\hline & & & & \multicolumn{4}{|c|}{$\left(\mathrm{MJ} \mathrm{m}^{-2} \mathrm{day}^{-1}\right)$} \\
\hline $174 / 2003$ & 0.74 & 0.55 & 1.38 & 12.77 & 1.84 & 31.85 & 36.65 \\
\hline $209 / 2004$ & 0.43 & 0.21 & 0.88 & 18.27 & 3.13 & 29.69 & 35.60 \\
\hline $195 / 2005$ & 0.46 & 0.35 & 1.59 & 17.76 & 3.01 & 30.46 & 37.77 \\
\hline $198 / 2006$ & 0.33 & 0.08 & 0.32 & 18.71 & 3.21 & 29.87 & 37.38 \\
\hline $185 / 2007$ & 0.41 & 0.17 & 0.62 & 16.34 & 2.74 & 31.28 & 38.39 \\
\hline $204 / 2008$ & 0.36 & 0.18 & 0.78 & 18.29 & 3.20 & 31.85 & 40.48 \\
\hline $238 / 2009$ & 0.40 & 0.18 & 0.87 & 22.34 & 3.83 & 30.40 & 37.72 \\
\hline $241 / 2010$ & 0.26 & 0.04 & 0.16 & 18.01 & 3.39 & 34.64 & 42.17 \\
\hline $196 / 2011$ & 0.35 & 0.11 & 0.50 & 16.95 & 2.98 & 31.54 & 39.04 \\
\hline
\end{tabular}

Considering all the images, $\mathrm{ET}_{\mathrm{a}}$ average was $0.79 \mathrm{~mm}_{\text {day }}{ }^{-1}$, however, when separating averages for the periods of 2003 to 2006 and from 2007 to 2011 , they went to 1.04 and $0.59 \mathrm{~mm}$ day ${ }^{-1}$, respectively. This $\mathrm{ET}_{\mathrm{a}}$ behavior is justified in Figure 3, by the values of NDVI, conclusion that becomes apparent when verifying the correlation between these variables, which presented an $\mathrm{R}^{2}$ of 0.59 , negatively influenced by the year of 2005 , which presented a difference of $\mathrm{NDVI}$ and $\mathrm{ET}_{\mathrm{a}}$ far superior to the ones obtained in other years.

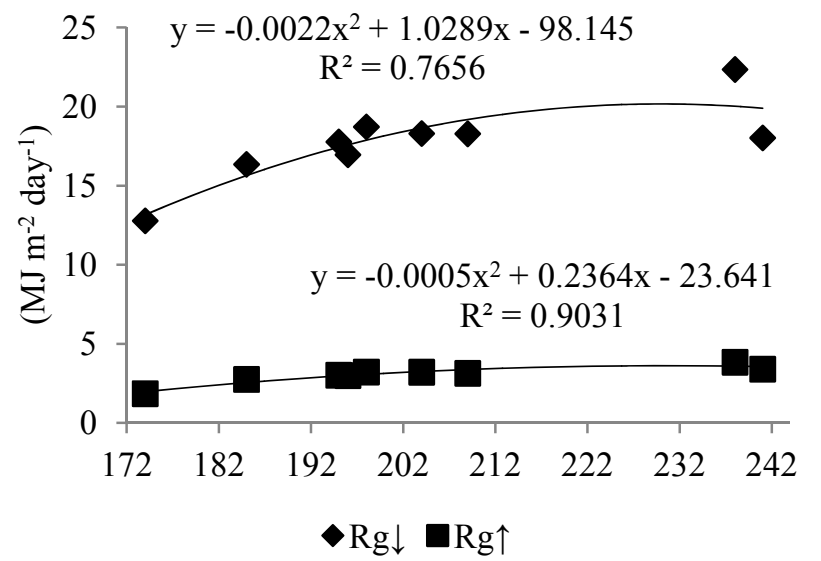

Figure 2. Values of $\mathrm{R}_{\mathrm{g} \downarrow} \downarrow$ and $\mathrm{R}_{\mathrm{g}} \uparrow$ in correlation with Julian Day (JD) of the image. 
NDVI behavior presented an average for the period of 0.42 , when separating into before and after the entrance of sugarcane, the average, respectively, went to 0.49 and 0.36 , these values occur due to the occurrence of recently planted areas and also harvest areas, which decreases the average value of NDVI in the Ipê's watershed.

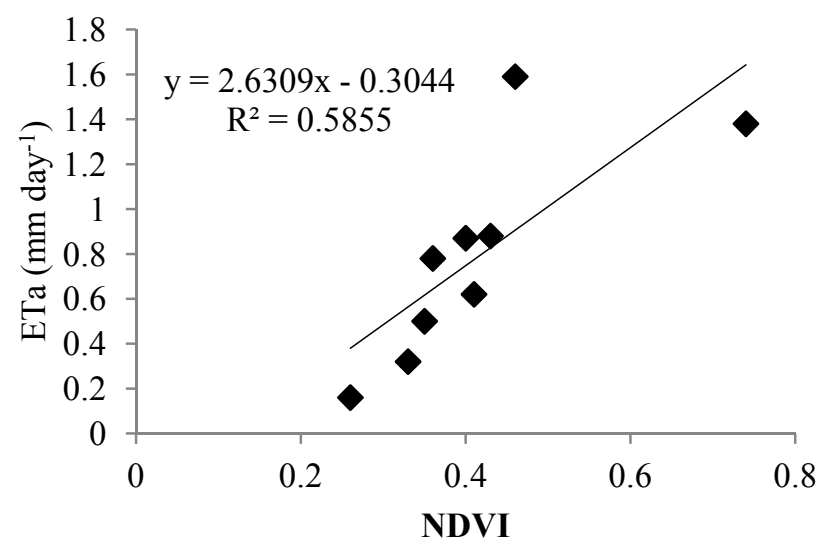

Figure 3. $\mathrm{ET}_{\mathrm{a}}$ and NDVI correlation.

The $\mathrm{ET}_{\mathrm{a}} / \mathrm{ET}_{0}$ presented in Table 2, show that there was a decrease in this ratio, where the average for the year of 2003 to 2006 was 0.28 , while in 2007 to 2011 , in the period where sugarcane was implanted in the region, reduced to 0.14 . This behavior has been proven opposite to what was expected, due to $\mathrm{Kc}$ being utilized for pasture irrigation ${ }^{24}$ is 0.80 , meanwhile sugarcane presents $\mathrm{Kc}$ superior to 0.80 starting at 91 days of age ${ }^{25}$, what would lead to believe a larger average of $\mathrm{ET}_{\mathrm{a}} / \mathrm{ET}_{0}$ after cane input.

However, cultivated cane in the studies' area were not irrigated and the crop coefficients, via rule are determined in great conditions of soil humidity and representing the potential condition, now related values in this study are current or real, representing the conditions of water restriction that the soil was found when the satellite passed. Also the obtained result is justified by the interference of harvest areas and of soil exposure in the cane areas.

Table 3. Julian Day (J.D.) and Year of Image, days without rain above of 10mm, last rain precipitation (mm) and accumulated precipitation $(\mathrm{mm})$ for Ipê's watershed.

\begin{tabular}{cccc}
\hline $\begin{array}{c}\text { D.J. and Year } \\
\text { of Image }\end{array}$ & $\begin{array}{c}\text { Days without rain } \\
\text { Above of 10 } \mathbf{~ m m}\end{array}$ & $\begin{array}{c}\text { Last rain } \\
\text { precipitation }\left(\mathbf{m m} \mathbf{~ d a y}^{\mathbf{- 1}}\right)\end{array}$ & $\begin{array}{c}\text { Acumulated } \\
\text { Precipitation } \mathbf{( m m})\end{array}$ \\
\hline $174 / 2003$ & 18 & 17 & 888.9 \\
$209 / 2004$ & 45 & 10.2 & 560.2 \\
$195 / 2005$ & 16 & 11.4 & 554.1 \\
$198 / 2006$ & 15 & 10.2 & 778.8 \\
$185 / 2007$ & 42 & 53.3 & 823.3 \\
$204 / 2008$ & 54 & 35.8 & 1276.7 \\
$238 / 2009$ & 6 & 58.9 & 847.2 \\
$241 / 2010$ & 113 & 12.5 & 693.1 \\
$196 / 2011$ & 36 & 50.3 & 961.7 \\
\hline
\end{tabular}


For the two periods, there were still found, in the years of 2006 and 2010, the lowest values for the evaluated period, respectively 0.08 and 0.04 , due to low soil humidity, during the date when the satellite passed in 2010 , the period without rain higher than $10 \mathrm{~mm}$ came up to 113 days (Table 3), although in 2006, the satellite's passage occurred 15 days after a rain of $10.2 \mathrm{~mm}$, however, previously, the region had gone 41 days without a precipitation superior to $10 \mathrm{~mm}$, which shows that $10.2 \mathrm{~mm}$ were not enough to gain ideal soil humidity in the image's data, considering that in this period the accumulated $\mathrm{ET}_{\mathrm{o}}$ was $55 \mathrm{~mm}$ and being the predominant soil, Argisol, which has available water capacity average of only $1.0 \mathrm{~mm} \mathrm{~cm}^{-1}$.

Observing that the fraction values $R_{n} / R_{g}$ (Table 4), it is seen that the average obtained for the evaluated period was of 0.43 , varying from 0.39 to 0.50 , however no variations were found in the evaluated period.

Table 4. Julian Day (J.D.) data and year of Image, Net Radiation $\left(R_{n}\right)$, ratio between Sensitive heat flux and Net Radiation $\left(H / R_{n}\right)$, ratio between Latent heat flux and Net Radiation $\left(\lambda E / R_{n}\right)$, ratio between $R_{n}$ and incident short waves $\left(R_{n} / R_{g} \downarrow\right)$, surface temperature (TS), surface Albedo $\left(\propto_{\mathbf{o}}\right)$.

\begin{tabular}{ccccccc}
\hline $\begin{array}{c}\text { D.J. and Year } \\
\text { of Image }\end{array}$ & $\begin{array}{c}\mathbf{R}_{\mathbf{n}} \\
\left(\mathbf{M J} \mathbf{~ m}^{-2} \mathbf{d a y}^{-\mathbf{1}}\right)\end{array}$ & $\mathbf{H} / \mathbf{R}_{\mathbf{n}}$ & $\lambda \mathbf{E} / \mathbf{R}_{\mathbf{n}}$ & $\mathbf{R}_{\mathbf{n}} / \mathbf{R}_{\mathbf{g}} \downarrow$ & $\mathbf{T S}\left({ }^{\circ} \mathbf{K}\right)$ & $\begin{array}{c}\text { Surface Albedo } \\
\left(\boldsymbol{\alpha}_{\mathbf{o}}\right)\end{array}$ \\
\hline $174 / 2003$ & 6.27 & 0.46 & 0.54 & 0.49 & 295.07 & 0.14 \\
$209 / 2004$ & 9.23 & 0.77 & 0.23 & 0.5 & 295.65 & 0.17 \\
$195 / 2005$ & 7.44 & 0.48 & 0.52 & 0.42 & 299.70 & 0.17 \\
$198 / 2006$ & 7.99 & 0.90 & 0.1 & 0.43 & 300.46 & 0.17 \\
$185 / 2007$ & 6.48 & 0.77 & 0.23 & 0.4 & 301.63 & 0.17 \\
$204 / 2008$ & 6.45 & 0.71 & 0.29 & 0.35 & 306.16 & 0.17 \\
$238 / 2009$ & 11.2 & 0.81 & 0.19 & 0.50 & 300.41 & 0.17 \\
$241 / 2010$ & 7.09 & 0.94 & 0.06 & 0.39 & 310.81 & 0.19 \\
$196 / 2011$ & 6.47 & 0.81 & 0.19 & 0.38 & 303.59 & 0.18 \\
\hline
\end{tabular}

A very similar result was obtained in the Irrigated District of Nilo Coelho, Brazil, where authors ${ }^{9}$ found average values of 0.46 of $R_{n} / R_{g}$, with minimum and maximum of 0.42 and 0.50 , respectively. The same author still justified the fact that data didn't follow a tendency, because the $R_{n} / R_{g}$ ratio is directly dependant of climatic conditions, where higher temperatures, increase the values of $R 1 \uparrow$, decreasing the $R_{n}$ and consequently the $R_{n} / R_{g}$ ratio.

Reverse behavior was observed for the $\lambda E / R_{n}$ ratio, where values presented a decrease of $45.7 \%$, going from an average of 0.35 from 2003 to 2006 , to an average of 0.19 for the period of 2007 to 2011 . But the ratio values for $H$ to $R_{n}$, in the same period, presented an increase after the year of 2007, going from an average of 0.65 to 0.81 , around $24.6 \%$, being that the biggest values were found in 2010 , where their ratio reached 0.94 in 2006 , with $H / R_{n}$ reaching 0.9 for the dry soil condition in these two dates.

The year of 2010 also presented higher values for TS for the evaluation period with an average of $310.81 \mathrm{~K}\left(37.6^{\circ} \mathrm{C}\right)$, contributing to the high values of $\mathrm{H} / \mathrm{Rn}$, where $94 \%$ of the net radiation was used in the sensitive heat flux, what generates soil, air and plant temperature elevation ${ }^{26}$. This affirmation justifies the behavior found for the values of surface temperature (Table 4) and reflected long radiation wave Rl $\uparrow$ (Figure 2), where the first parameter presented an average of $297.72 \mathrm{~K}\left(24.57^{\circ} \mathrm{C}\right)$ before sugarcane culture implantation, going from an average of $304.52 \mathrm{~K}\left(31.37^{\circ} \mathrm{C}\right)$ after

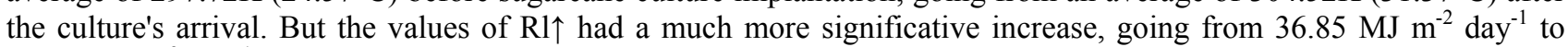
$39.56 \mathrm{MJ} \mathrm{m}^{-2}$ day $^{-1}$, representing an increase of $7.4 \%$ after the cane's entry, superior increase to the occurred for the data of R1 $\downarrow$ was of $4.8 \%$ for the same period.

Other authors ${ }^{27}$ also relate the increase of TS with surface albedo increase, consequently, decreasing the Rn, behavior similar to the one found in the Ipê's watershed area, also with the increase of values of TS, Rl $\uparrow$ and Rl $\downarrow$, an increase in the values of $\propto_{o}$ (Table 4) can be observed, which represented an average of 0.17 for the evaluated period, being so the minimum obtained 0.14 in 2003 and maximum of 0.18 and 0.19 , respectively in the years of 2011 and 2010, behavior as such is due to the presence of sugarcane harvest areas. 
The results for $R_{n}$ also presented a decrease throughout the years, going from an average of $7.73 \mathrm{MJ} \mathrm{m}^{-2}$ day ${ }^{-1}$ between 2003 and 2006 for $7.54 \mathrm{MJ} \mathrm{m}^{-2}$ day $^{-1}$ of 2007 to 2011 . However, the highest value of $\mathrm{R}_{\mathrm{n}}$ for the whole evaluated period, was obtained in the year of 2009 , where an average of $11.2 \mathrm{MJ} \mathrm{m}^{-2} \mathrm{day}^{-1}$ was reached, with values close to ones found in literature ${ }^{28}$, which presents an average $R_{n}$ of $11.08 \mathrm{~m}^{-2}$ day $^{-1}$ in the period of 2004 to 2005 for a culture of irrigated mango in the basin region of the São Francisco river, similarity which can associated to the rain occurred in days leading to the satellite's passage ${ }^{29}$, such a relevant observation to the case, being that 2009 was the year that presented the shortest period of days without rain before image capture (Table 3 ).

Observing the values of $\mathrm{ET}_{\mathrm{a}}, \mathrm{H} / \mathrm{R}_{\mathrm{n}}, \lambda \mathrm{E} / \mathrm{R}_{\mathrm{n}}$ and TS, separately for the targets of green cane, harvested cane, urban area and pasture for the period of 2007 to 2011, it is possible to observe that all of them present the same behavior, however the green cane showed the highest values of $\mathrm{ET}_{\mathrm{a}}$ and $\lambda \mathrm{E} / \mathrm{R}_{\mathrm{n}}$ and the smallest for $\mathrm{H} / \mathrm{R}_{\mathrm{n}}$ and TS (Figura 4), where the highest values of sugarcane $\mathrm{ET}_{\mathrm{a}}$, show that this culture presents $\mathrm{K}_{\mathrm{c}}$ values higher than pasture, which confirms the $\mathrm{K}_{\mathrm{c}}{ }^{25}$ data previously cited for cane and pasture ${ }^{24}$, which confirms that the lower values of current $\mathrm{K}_{\mathrm{c}}$ found for the period of 2007 to 2011 in relation to the period of 2003 to 2006 (Table 2), were influenced not only by the sugarcane and pasture, but also by the areas of harvested cane and exposed soil, which present similar characteristics to that of pasture.
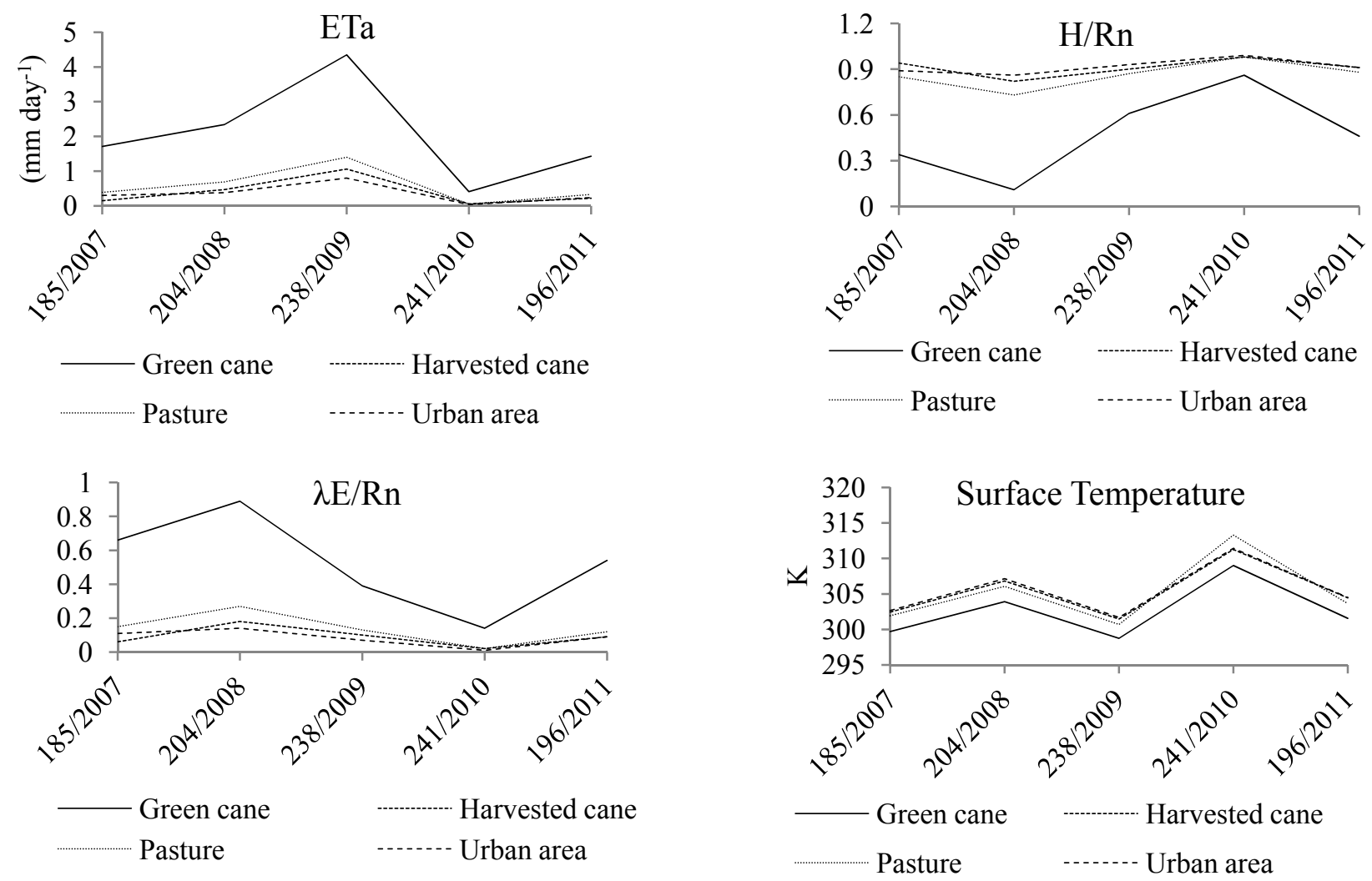

Figure 4. Average $\mathrm{ET}_{\mathrm{a}}, \mathrm{H} / \mathrm{R}_{\mathrm{n}}, \lambda \mathrm{E} / \mathrm{R}_{\mathrm{n}}$ and surface temperature values, for the classes of green cane, harvested cane, pasture and urban area, throughout the years.

The other targets presented values very similar to one another, showing that green cane areas differ from other targets, for the most $\mathrm{ET}_{\mathrm{a}}$ and lower $\mathrm{T}$, showing that the entry of sugarcane culture may have influenced the energy balance in Ipê's watershed. 


\section{CONCLUSIONS}

The $\mathrm{ET}_{\mathrm{a}}, \mathrm{H} / \mathrm{R}_{\mathrm{n}}, \mathrm{TS}, \mathrm{Rl} \uparrow, \mathrm{R} 1 \downarrow$ and albedo surface values, present an increase in their values in the period of 2007 to 2011 , meanwhile the NDVI, $\lambda E / R_{n}$ and $R_{n}$ data present a reduction in average values.

The green cane areas presented in between harvested sugarcane areas, pastures and urban area, the highest $\mathrm{ET}_{\mathrm{a}}$ and lowest surface temperature, showing that the entry of the culture in the watershed may have influenced the energy balance since 2007 .

These results show the need of a study with a larger number of images to verify, with precision, the interference of entry of sugarcane culture in the energy balance of the Ipê's watershed, in order to obtain less influence in the sugarcane harvest areas in average watershed values.

The SAFER model presented satisfactory results for the to evaluate the components of the energy balance in the northwest region of São Paulo State.

\section{ACKNOWLEDGEMENTS}

To FAPESP and CNPq for their financial support.

\section{REFERENCE LINKING}

[1] Camargo, A.M.M.P., Caser, D.V., Camargo, F.P., Olivette, M.P.A., Sachs, R.C.C., Torquato. S.A., "Dinâmica e tendência da expansão da cana-de-açúcar sobre as demais atividades agropecuárias, estado de São Paulo, 2001-2006," Informações Econômicas, 38(3), 47-66 (2008).

[2] Santos, G.O., Hernandez, F.B.T., "Uso do solo e monitoramento dos recursos hídricos no córrego do Ipê, Ilha Solteira, SP," Revista Brasileira de Engenharia Agrícola e Ambiental, 17(1), 60-68 (2013).

[3] Freitas-Lima, E.A.C., Silva, H.R., Altimare, A.L., "Uso atual da terra no município de Ilha Solteira, SP, Brasil: riscos ambientais associados. Holos Environment," 4, 81-96 (2004).

[4] Palla, G.O., Silva, G.N.R., Silva, H.R., Marques, A.P., Holanda, H.V., Astolfi, T.B., Zocoler, J.V.S., Cézar, F.R.G. "Potencial de expansão da cultura de cana-de-açúcar (Saccharum spp.) no município de Ilha Solteira/SP," In: SBSR Simpósio Brasileiro de Sensoriamento Remoto 15, Curitiba. INPE, ISBN: 978-85-17-00057-7 (2011).

[5] Compaoré, H., Hendrickx, J.M., Hong, S., Friesen, J., Giesen, N.C., Rodrigues, C., Szarzynski, J.,Vlek, P.L.G., "Evaporation mapping at two scales using optical imagery in the White Volta Basin, Upper East Ghana," Physics and Chemistry of the Earth, 33, 127-140 (2008).

[6] Teixeira, A.H.C., Bastiaanssen, W.G.M., Ahmad, M.D., Bos, M.G. "Reviewing SEBAL input parameters for assessing evapotranspiration and water productivity for the Low-Middle São Francisco River basin, Brazil Part A: Calibration and validation," Agric. For. Meteorol, 149, 477-490 (2009).

[7] Teixeira, A.H.C., "Determining regional actual evapotranspiration of irrigated and natural vegetation in the São Francisco river basin (Brazil) using remote sensing an Penman-Monteith equation," Rem. Sens, 2, 1287-1319 (2010). 
[8] Hernandez, F.B.T.; Neale, C.; Taghvaeian, S. Teixeira, A.H.C. "Avaliação preliminar do modelo SEBAL para a estimativa da distribuição espacial da evapotranspiração em áreas irrigadas no noroeste paulista," In: SBSR Simpósio Brasileiro De Sensoriamento Remoto 15, Curitiba. INPE, ISBN: 978-85-17-00057-7 (2011).

[9] Teixeira, A.H.C., Hernandez, F.B.T., Lopes, H.L. "Application of Landsat images for quantifying the energy balance under conditions of land use changes in the semi-arid region of Brazil," In: SPIE Remote Sensing Symposium, Edinburgh. Proceedings of SPIE, 8531, 85310P1-85310P-2. (2012).

[10] Damião, J. O., Hernandez, F. B. T., Santos, G. O., Zocoler, J. L., "Balanço hídrico da região de Ilha Solteira, Noroeste Paulista. In: Congresso Nacional de Irrigação e Drenagem," Uberaba. 2010. <http://www.agr.feis.unesp.br/pdf/conird2010_damiao.pdf> (15 abr. 2013).

[11] Hernandez, F. B. T., Souza, S. A. V., Zocoler, J. L., Frizzone, J. A. "Simulação e efeito de veranicos em culturas desenvolvidas na região de Palmeira d'Oeste, Estado de São Paulo," Engenharia Agrícola, 23(1), 21-30 (2003).

[12] Hernandez, F. B. T., Lemos Filho, M. A. F., Buzetti, S. "Software HIDRISA e o balanço hídrico de Ilha Solteira," Ilha Solteira: UNESP, 45p. (1995).

[13] Santos, G. O., Hernandez, F. B. T., Rossetti, J. C., "Balanço hídrico como ferramenta ao planejamento agropecuário para a região de Marinópolis, noroeste do Estado de São Paulo," Revista Brasileira de Agricultura Irrigada, 4, 142-149 (2010).

[14] Ilha Solteira., "Plano Diretor do Município de Ilha Solteira," Lei Complementar No 151, 1 julho 2008, <http:/www.ilhasolteira.sp.gov.br/planodiretor/images/Leic-151.pdf> (10 junho 2013).

[15] Allen, R. G., Pereira, L. S., Raes, D., Smith, M. "Crop evapotranspiration: guidelines for computing crop water requirements, (FAO. Irrigation and Drainage Paper, 56)." Rome: FAO, 300 (1998).

[16] UNESP, “Canal Clima da UNESP Ilha Solteira - Área de Hidráulica e Irrigação,” < http://clima.feis.unesp.br > ( 2 mar 2013).

[17] Chander, G., Markham, B., "Revised Landsat-5 TM radiometric calibration procedures and postcalibration dynamic ranges," Ieee Transactions On Geoscience And Remote Sensing, 41(11), 2674-2677 (2003).

[18] Chander, G., Markham, B., Helder, D. L. "Summary of current radiometric calibration coefficients for Landsat MSS, TM, ETM+, and EO-1 ALI sensors," Remote Sensing Of Environment, 893-903 (2009).

[19] Hernandez, F. B. T., Teixeira, A. H. C., Neale, C. M. U., Taghvaeian, S., "Determining actual evapotranspiration on the large scale using agrometeorological and remote sensing data in the Northwest of the São Paulo State, Brazil," In: International Symposium on Irrigation of Horticultural Crops, $7^{\circ}$, Geisenheim - Alemanha, Proceedings, 51. (2012).

[20] Teixeira, A. H. C., Bastiaanssen, W. G. M., Ahmad, M. D., Bos, M. G., “Analysis of energy fluxes and vegetationatmosphere parameters in irrigated and natural ecosystems of semi-arid Brazil,” J. Hydrol., 362, 110-127 (2008).

[21] Rudorff, B. F. T., Aguiar, D. A., Silva, W. F., Sugawara, L. M., Adami, M., Moreira, M. A., "Studies on the rapid expansion of sugarcane for ethanol production in São Paulo State (Brazil) using Landsat Data," Remote Sensing, 2, 1057-1076 (2010). 
[22] Adami, M., Mello, M. P., Aguiar, D. A., Rudorff, B. F. T., Souza, A. F. D. "A Web Platform Development to Perform Thematic Accuracy Assessment of Sugarcane Mapping in South-Central Brazil," Remote Sensing, 4, 3201-3214 (2012).

[23] Oliveira, G., Moraes, E. C., Rudorff, B. F. T., Moura, Y. M., "Balanço de radiação em áreas de expansão do cultivo da cana-de-açúcar no estado de São Paulo nas safras 2006/2007 e 2007/2008," In: SBSR Simposio Brasileiro de Sensoriamento Remoto, 16. Foz do Iguaçu. 1099$1106(2013)$.

[24] Alencar, C. A. B., Cunha, F. F., Martins, C. E., Cóser, A. C., Rocha, W. S. D., Araújo, R. A. S. "Irrigação de pastagem: atualidade e recomendações para uso e manejo," R. Bras. Zootec., 38, 98-108 (2009).

[25] Dalri, A. B., Cruz, R. L., "Produtividade da cana-de-açúcar fertirrigada com N e K via gotejamento subsuperficial," Eng. Agríc., 28(3), 516-524 (2008).

[26] Franco, R. A. M., Hernandez, F. B. T., Teixeira, A. H. C., Feitosa, D.G., "Avaliação do balanço de energia em diferentes tipos de uso e cobertura da terra na região noroeste do Estado de São Paulo," In: SBSR Simposio Brasileiro De Sensoriamento Remoto 16. Foz do Iguaçu. 6909-6916 (2013).

[27] Gomes, H. B., Silva, B. B., Cavalcanti, E. P., Rocha, H. R., "Balanço de radiação em diferentes biomas no estado de São Paulo mediante imagens landsat 5," Geociências, 28(2), 153164 (2009).

[28] Teixeira, A. H. C., Bastiaanssen, W. G. M., Moura, M. S. B., Soares, J. M., Ahmad, M. D., Bos, M. G., "Energy and water balance measurements for water productivity analysis in irrigated mango trees, Northeast Brazil," Agricultural And Forest Meteorology, 148, 1524-1537 (2008).

[29] Silva, B. B., Lopes, G. M., Azevedo, P. V., "Balanço de radiação em áreas irrigadas utilizando imagens Landsat 5 - TM," Revista Brasileira de Meteorologia, 20(2), 243-252 (2005). 